\title{
Editorial
}

\section{Security Mechanisms for the Autonomy of the Third Power in Europe!}

Art. 92(1) of the Basic Law describes the separation of powers in a democratic, rule-oflaw state with these words: "The judicial power is entrusted to the judges." The independence of the individual judges is an uncontroversial, actively held principle in the German judicial system's legal practice. This is affirmed particularly by the reformers who do not believe that the organizational-institutional independence of the third power in Germany is in line with the constitutional principle of effective separation of powers: "We have good, well-qualified judges. The results are respectable in international comparisons," said Hans-Ernst Böttcher when retrospectively looking at his lifelong work for judicial autonomy. This evaluation, however, is placed within a logical plea to bring the administration and organization of the judiciary system up to a comparable level (SchlHAnz 2014, p. 432 (434)). Böttcher agrees with the three large German judges associations. Their actions can also be summarized by the title of his review of his professional career: "I poured out most of my sweat and ink for the independence of the judiciary." The development toward more autonomy and the search for institutional conditions for securing this autonomy are underway across Europe: each country is taking up this task in its own way depending on the respective historical and political requirements.

With this background it is highly admirable that the Federal Ministry of Justice, several Länder Ministries of Justice, and the three large judges associations in Germany set off together in search of real-life experiences of practiced institutional autonomy of the third power in Europe. This special issue 4/2014 of the Critical Quarterly for Legislation and Law reports on the results and prospects for application of the long search by the Federal-Länder Commission "Judicial System."

In the first section, the Commission presents its empirical results in a summary of the four discussions with judicial delegations from the Netherlands, Italy, Poland, and Switzerland. A short description of the history of the Commission (A) and the discussion questions (B) is given. In the third section (C), the "Country-specific summaries" are presented. Following the topics of the discussion questions, the issues are

- Legitimation of autonomy in the four judicial systems (I),

- The influence of organizational structure on human resource issues (II),

- The efficiency and quality of adjudication (III),

- The link between the judiciary and the public (IV), and

- The special situation of the state prosecutor's office in the respective judicial system (V).

In this publication, the survey results are based on the extensive minutes created by the Commission's academic assistant Mareike Jeschke from the translated tape recordings (210 typed pages). The complete minutes can be read in the annex to her forth- 
coming dissertation publication. The source citations in the printed version here refer to the complete manuscripts of the respective country minutes (Jeschke, Diss., Frankfurt/M., 2015).

In a second section, the debate of the German Commission "Judicial System" with the Council of Europe's working group Consultative Council of European Judges (CCJE) is described in a personal contribution by Peter-Alexis Albrecht. The CCJE working group was invited to the debate by the Federal Ministry of Justice and Consumer Protection. The debate, which lasted an entire day, took place on 23 June 2014 in Berlin. The results from the country minutes were summarized by the moderator and used to stimulate the discussion. These can be found ahead of the respective CCJE discussion comments in the contribution "Security Mechanisms for the Autonomy and Independence of the Judiciary." The CCJE working group agreed to the publication of their views. With the exception of some informational questions by the German participants, the entire minutes can be read in the annex to M. Jeschke's dissertation.

The debate with the four countries and the CCJE advisory board was not linked to the concrete legal policy discussion of the German judges associations. It should be understood instead as a fundamental search for security mechanisms for the independence and impartiality of the European judiciary as a whole. The following issues were focused upon:

- How should the third power be legitimized: with direct elections, parliamentary elections, independent appointment commissions, judges' selection committees as is done in some German Länder, or by the ministry's selection, appointment, and promotion of judges?

- Which is more important: parliamentary election or guarantees of independence in selecting judges?

- How can political influence on judges' elections be avoided or is it desired?

- Why is a high degree of legitimacy required for the third power? Or is the practiced limitation of powers not rather proof that all state powers are obligated to uphold the common good?

- How does the strength of independent legitimation affect the judges' self-understanding?

- Which advantages and which difficulties can be seen in the dual control models of ministries of justice (executive) and independent judges' councils (judicial) set up primarily in Europe?

- How do mechanisms of executive personnel control or the forgoing of such mechanisms affect judicial autonomy?

- How should the lack of intrinsic motivation and the danger of judges' resignation be avoided? Are there conditions that could be set up to avoid these developments?

- Which security mechanisms are available for promoting the efficiency and quality of adjudication?

- How does judicial self-administration affect adjudication?

- What experiences are there with the third power having budgetary authority?

- How does institutional autonomy affect the judiciary's dealings with the public and media? Are improvements in the judiciary's communication abilities in sight, is there more transparency, and are there accepted rules for communicating with the public and media? 
- And finally: Which developments and experiences are there in other countries regarding an independent state prosecutor's office?

The complexity of the questions makes it clear that securing the third power's autonomy will be a permanent legal policy concern for all of Europe. The discussion moderator's summary of "ten security mechanisms for the autonomy of the third power in Europe" (Section F) therefore follows an ambitious legal policy program that still needs a broader public and internal judicial debate before being implemented in Germany. Particularly in Germany it becomes clear that the ball is not in the executive's court that is, the ministries of justice - or even in the legislature's. Since these agencies could fear a loss of power and intensification of control if the judiciary were to get more autonomy, the initiative can only come from the third power itself. The activity of the professional judges associations indicates this.

From the Netherlands and Norway one can hear: The discussion of the questions listed above must take place by the judges themselves. Each of the questions mentioned is a challenge for each individual judge, and the recommendation from the Netherlands should not fall on deaf ears within the judges' ranks: "Start immediately: without a constitutional amendment, without changing the current structures!" was the recommendation of the CCJE President Bart van Lierop; and he encourages from his own experience: "Throw off your chains! Emancipate yourselves!"

And in fact: the autonomy of the third power is not a gift from the legislative or executive branches. The experiences and appeals from the CCJE working group lend reassurance and encourage activities led by the judges themselves. To this extent, selfadministration in the third power would be the development of institutional autonomy - in Germany, as well. In any case, in terms of the constitution, it is a logical consequence of the basic democratic demand for the separation of powers. The judges are called upon to follow this principle. If they do not, then the law will lose its power.

Berlin, im November 2014

Peter-Alexis Albrecht 